\title{
Reducing Land Degradation on the Highlands of Kilimanjaro Region: A Biogeographical Perspective
}

\author{
Christine Noe \\ Department of Geography, University of Dar es Salaam, Dar es Salaam, Tanzania \\ Email: cnpallangyo@gmail.com, tinanoe@yahoo.com \\ Received 1 October 2014; revised 8 November 2014; accepted 26 November 2014 \\ Copyright (C) 2014 by author and Scientific Research Publishing Inc. \\ This work is licensed under the Creative Commons Attribution International License (CC BY). \\ http://creativecommons.org/licenses/by/4.0/ \\ (c) (i) Open Access
}

\begin{abstract}
In 2012, governments across the world adopted "The Future We Want" outcome document in Rio De Janeiro as a commitment to achieve a land-degradation-neutral world. This document reasserts the importance of sustainable land management in the top of the debates on sustainable development. This paper provides an overview of Tanzania's preparedness towards achieving these global objectives. The paper is based on a keynote address which was presented in the conference on reducing land degradation on the highlands of Kilimanjaro Region in Tanzania. Using a biogeographical perspective, the paper assesses challenges of adopting programmatic approach to sustainable land management in Tanzania. It also presents some opportunities that exist through Global Mechanism of the United Nations Convention to Combat Desertification, which promote actions leading to coordination, mobilization and channeling of financial resources to assist member countries to coordinate and sustain sustainable land management projects.
\end{abstract}

\section{Keywords}

Sustainable Land Management, Bioregional Planning, Kilimanjaro, Tanzania

\section{Introduction}

Recent analyses of global trend of land degradation reassert that there is a close relationship between land degradation and human welfare (poverty or development) [1]. A study by the Food and Agriculture Organization (FAO) (2011) demonstrates that $25 \%$ of global land is highly degraded and $40 \%$ of this degradation occurs in areas with high poverty rates. It is argued that poor people have the least access to land and water, they depend on small farms (most of which are in poor quality soils) and they have least access to modern farm technologies, 
which make them most vulnerable to land degradation and climatic uncertainties [1] [2]. Notably, Pingali et al. [1] demonstrate that across Sub-Saharan Africa, poverty coincides with marginal environments. This put Sustainable Land Management (SLM) at the top of the global sustainable development agenda. Indeed, in June 2012, governments adopted "The Future We Want" outcome document in Rio De Janeiro, which recognized that poverty eradication was an indispensable requirement for sustainable development (in paragraph 2) and the need for urgent action to reverse land degradation (in paragraph 206). Throughout this document, countries agreed to strive to achieve a land-degradation-neutral world in the context of sustainable development [3].

This paper was presented in April 2014 as a keynote address in a conference on reducing land degradation in the slopes of Mount Kilimanjaro, Tanzania. Being a human geographer, my approach to this task was guided by the bioregional planning model, which paid particular attention to human-nature interactions. Notably, the address focused on the relationship between land degradation and how nature-human landscapes were managed in Tanzania. Since the Rio Earth Summit of 1992, local responses to land degradation and related problems have varied from area-specific and nationwide to short-term and long-term projects and programs. Tanzania's involvement in these international development debates and the signing of various agreements attests to the country commitment to reducing land degradation and related socio-economic and environmental impacts. Among others, Tanzania agreed to the terms of the United Nations Convention to Combat Desertification (UNCCD), the Convention on Biological Diversity (CBD) and related protocols, the United Nations Framework Convention on Climate Change (UNFCCC), the Kyoto Protocol and the Convention on International Trade in Endangered Species of Wild Flora and Fauna (CITES), to mention a few.

These international conventions informed nationwide actions leading to policies and strategies to address environmental problems generally and land degradation in particular. The first National Environment Policy (NEP, 1997) and National Action Programme (NAP, 2004) formed the basis for the implementation of actions relating to sustainable resource management and combating degradation and desertification. There are several other policies and strategies that form a national framework for facilitating the achievement of these objectives including the Poverty Reduction Strategy Paper (PRSP) (2000), Tanzania Development Vision 2025 (2001), Rural Development Strategy (2001), the Agricultural Sector Development Strategy (ASDS) (2001), National Environmental Management Act (2004) as well as the National Strategy for Economic Growth and Reduction of Poverty (2005). Despite these national efforts, Tanzania still suffers from widespread land degradation [4]. Agricultural land in particular is continuously under pressure from factors associated with inappropriate land use practices such as poor crop cultivation practices, overgrazing, deforestation and bush fires, which have weakened land productive capacity. Specifically in the case of Kilimanjaro, I discuss the opportunities that exist for adopting programmatic approaches to SLM in Tanzania.

\section{The Context of Kilimanjaro: The Bioregional Model and Sustainable Land Management}

The Kilimanjaro Mountain is part of a large ecosystem which forms an important human-nature landscape that straddles local and international political borders. Precisely, the nature landscape encompasses the Kilimanjaro national park and forest reserve (in Tanzania) and Amboseli and Tsavo West national parks (in Kenya). There are wildlife corridors that establish ecological connectivity within and beyond the landscape including with the neighboring protected areas such as Arusha and Mkomazi national parks and Meru forest reserve. The Kilimanjaro ecosystem hosts about 2500 plant and 179 birds' species, some of which are endemic to the area. These characteristics, coupled with Kilimanjaro being the highest mountain in Africa, afforded the ecosystem the status of a Biosphere Reserve and World Heritage Site since 1989. In terms of human landscape, the Kilimanjaro administrative region is about $1.4 \%$ of the total land mass of Tanzania. According to the 2012 census, the region is a homeland of $4 \%$ of the total country population [5]. Combined, these statuses make Kilimanjaro an important bioregion, a description that I discuss in this section.

In the recent debates, the use of economic aspects of nature as a means for achieving both conservation and development objectives prompted the adoption of a bioregional planning model. The model is based on the UNESCO's Man and Biosphere Reserves concept of geographical zoning, which comprises clearly delineated and legally protected core areas, buffer zones and cooperation areas [6] [7]. While core areas are devoted to the protection of the environment and its biological diversity, each of them should be surrounded by a well defined buffer zone where only activities compatible with the conservation objectives may take place. To the extent 
possible, buffer zones provide cushion to core areas, provide connectivity in the landscape via ecological corridors and meet their function as stand-alone polygons.

Cooperation zones (also known as agro ecological zones/productive human landscapes) are important areas where new approaches to sustainable resource management initiatives and practices are encouraged, with the cooperation of the human population [6]. This is where multiple land uses such as forestry, agriculture, settlements and other human related activities are found. The zone is therefore a core of SLM practices and application of sustainable development principals and strategies.

As demonstrated in Figure 1 (left), bioregional borders are metaphorical, which translate that bioregions are natural and therefore permeable. For this reason, different natural and human-induced forces have often redefined borders of bioregions. Often, these forces come from the cooperation/productive zone where actions are required to translate the use of resources into real development through control of soil erosion and enhancement of land productivity, water and biodiversity conservation and sustainable options for household food security and income. However, the proponents of bioregional model recognize the cooperation zone as an important tool for the harmonization of the often conflicting objectives of intensified economic and social development while maintaining and enhancing the ecological and global life support functions of land resources. It is against this background that, in my view, thinking in terms of the three components of a bioregional planning model would be a useful starting point for the evaluation of SLM projects that seek to improve land productivity and its subsequent impacts on development.

Different studies that have assessed the rate of land degradation in the Kilimanjaro bioregion support that the level of threats has progressively increased in the past two decades. Some of the major observable threats have been disconnection of core protected areas following the disappearance of ecological corridors. For example, with the exception of the Kilimanjaro-Amboseli migration route, all other ecological corridors that connected Kilimanjaro national park with the surrounding ecosystems in Tsavo West, Mkomazi and Arusha national parks have all been blocked by human activities [8]. Reports of different research projects support the view that the Kilimanjaro bioregion has increasingly been under threat from different forces. In particular, a collaborative research by the UNDP/UNEP, Kenya Wildlife Service (KWS), Wildlife Conservation Society of Tanzania (WCST) and the University of Bayreuth investigated threats to the forests of Kilimanjaro in 2002. The report from this research is the source of Figure 1 (right), which suggest that the whole area of the forest belt of Mount Kilimanjaro is disturbed by human activities through illegal logging of indigenous trees, fire occurrences on the

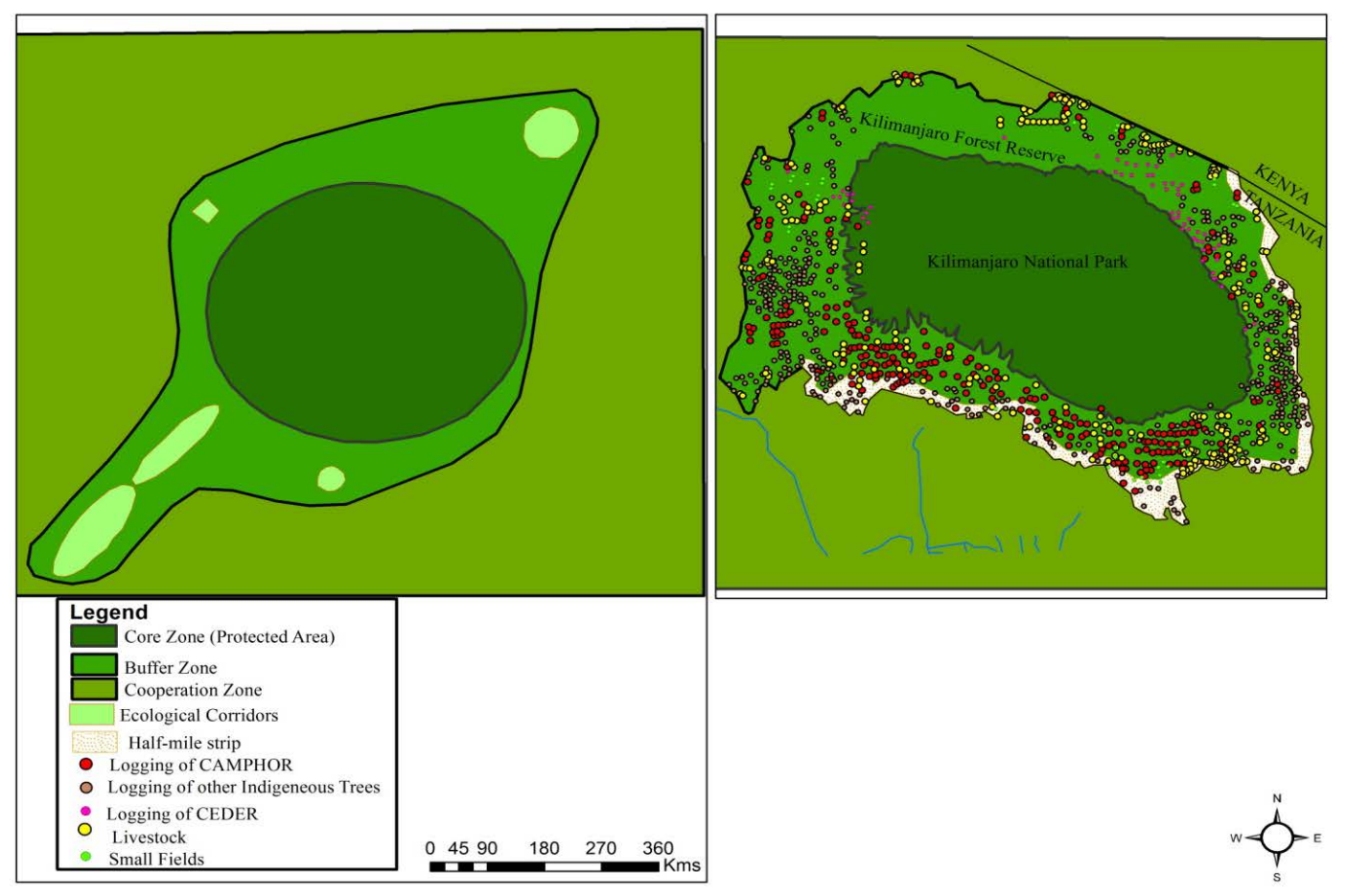

Figure 1. The Kilimanjaro bioregion. Source of the model: Adopted from [6] page 149. 
south eastern slopes and the establishment of forest villages in the western and northern slopes [9].

Another project called Land Use Change, Impacts and Dynamics (LUCID) indicated that there has been a decreasing trend for pasture and fodder, native vegetation, accessibility to key resources in grazing areas, and wildlife movement corridors, diversity and distribution ranges of all ecosystems [10]. In the same time, the project recorded increasing trends for soil erosion, pastoral-farmer and human-wildlife conflicts, all of which were associated with water and pasture scarcity as well as wildlife habitat fragmentations [8] [11].

Other recent studies such as those by Soini [12] and Hemp [13] report declining agro-forestry system in Kilimanjaro following changes in Chagga home gardens which have long been a source of livelihoods, biodiversity habitat and refuge area for plants and animals. As in the previous, these studies associate the declining trend with land fragmentation particularly following changes in local land management and ownership (the kihamba system) and the management of commercial coffee plantations. The later has meant that, there is no need to retain a tree canopy layer anymore although demands for commercial and domestic wood continues to increase hence putting more pressure on both reserved and sacred forests. Indeed, Ylhäisi [14] demonstrates how indigenous forests in North Pare lost its cover by 95\% during 1982-1997 while the cultivated land area increased by $68 \%$ [14]. Overall, changes in land cover and use have increasingly affected microclimate, land management and biodiversity conservation in the region [12] [13].

Although levels of threats to biodiversity have been growing, community participation in conservation that has been spearheaded by various actors has worked to protect nature from further encroachments. For example, the UNDP and the United Nations Foundation facilitated the Community Management of Protected Areas Conservation Project (COMPACT) around Mount Kilimanjaro since early 2000s. The project was significantly successful in bringing human and nature landscapes into the management practices of protected areas through local-based initiatives which have also proved to sustain local livelihoods [9] [15]. This project suggests therefore that although SLM projects in Kilimanjaro are implemented by different actors, they respond variously to the calls for sustaining nature and human landscape in this changing socio-economic and biophysical environment.

The government of Tanzania and its different development partners facilitate the implementation of the bioregional model through formulation and implementation of policies and project objectives that seek to achieve sustainable development by reconciling economic growth and conservation of resources. My assessment of these efforts reveals that since 2005 over 100 projects of bioregional nature have been implemented countrywide. Of these, five are on-going in Kilimanjaro Region (Table 1). This list is limited to those projects that are strictly operating on the ground hence excluding national wide programs and old projects. A more detailed list of these projects is provided by Mashauri [16].

\section{Challenges of Adopting Programmatic Approach to Sustainable Land Management}

The SLM project in Kilimanjaro commissioned various consultants who provided detailed technical assessments

Table 1. SLM/bioregional projects in Kilimanjaro Region.

\begin{tabular}{|c|c|c|c|c|}
\hline $\mathbf{S} / \mathbf{N}$ & Name & Project objectives & SLM component & Main actors \\
\hline 1 & $\begin{array}{l}\text { Sustainable land } \\
\text { management }\end{array}$ & $\begin{array}{l}\text { Reducing land degradation on the } \\
\text { highlands of Kilimanjaro }\end{array}$ & $\begin{array}{l}\text { All resources (agricultural } \\
\text { land, forest, water, wildlife) }\end{array}$ & $\begin{array}{c}\text { Vice President's } \\
\text { Office/Kilimanjaro Regional } \\
\text { Administration and UNDP/GEF }\end{array}$ \\
\hline 2 & Maasai steppe heartland & $\begin{array}{l}\text { Scaling up conservation and } \\
\text { livelihood efforts in northern } \\
\text { Tanzania (SCALE-TZ) }\end{array}$ & Biodiversity & $\begin{array}{c}\text { African Wildlife } \\
\text { Foundation/USAID }\end{array}$ \\
\hline 3 & $\begin{array}{l}\text { Wildlife management } \\
\text { areas and environmental } \\
\text { management policy program } \\
\text { (SCAPES) }\end{array}$ & $\begin{array}{l}\text { Implement environmental and natural } \\
\text { resources policy programs through the } \\
\text { application of wildlife management } \\
\text { areas (WMAs) regulations and } \\
\text { environmental management act }\end{array}$ & Wildlife and livelihoods & WWF/USAID \\
\hline 4 & $\begin{array}{l}\text { Women and organic } \\
\text { agriculture }\end{array}$ & $\begin{array}{l}\text { Improved livelihoods for women } \\
\text { through organic agriculture }\end{array}$ & Agricultural development & Floresta/USAID \\
\hline 5 & $\begin{array}{l}\text { Participatory forest } \\
\text { management (PFM) }\end{array}$ & $\begin{array}{l}\text { Improved sustainable forests and } \\
\text { woodland resources for sustainable } \\
\text { livelihoods }\end{array}$ & Forest and livelihoods & $\begin{array}{l}\text { DANIDA/Ministry of Natural } \\
\text { Resources and Tourism }\end{array}$ \\
\hline
\end{tabular}


on specific thematic areas including on the issues of fuel efficient technologies for domestic, institutions and industrial use (by Camco Cleanenergy Ltd.); extension service delivery in SLM activities (by SUA); decision-making tools to facilitate village land-use planning (SUA-Bureau of Agricultural Consultancy and Advisory Service (BACAS); gender mainstreaming (by Moshi University of Cooperatives and Business Studies) and issues of policy review, harmonization, and traditional institutions (by Alpha and Omega Ltd.). These assessments contribute to this special issue. I should commend the project management for according due importance to these issues given their relevance in ensuring success of the project.

Meanwhile, the Global Mechanism of the United Nations Convention to Combat Desertification (UNCCD) commissioned different studies with the aim of assisting Tanzania to formulate an Integrated Investment Framework for SLM (IIF). These studies were conducted on different aspects including the economic valuation of land [17]; promotion, mobilization and innovation of financing mechanisms [18]; financial instruments associated with incentives and market-based mechanisms (IMBMs) [16] and on Aid for Trade (AfT) [19]. Among other things, these studies identify major constrains that hinder SLM progress in Tanzania generally and proposes a model for promoting SLM [4]. Important for the current section will be the challenges that these different studies have identified and ways that they reflect local circumstances in Kilimanjaro.

The various diagnostic studies indicate that although the country has implemented many programmes and projects to counteract degradation since colonial times, Tanzania still suffers from widespread land degradation. These studies suggest that the growing trend of degradation owes generally to systemic problems associated with the promotion of SLM in the country [4]. These have ranged from financial, organizational, technical and more so the innovations on how to upscale and mainstream SLM. Other causes of the problem are associated with lack of knowledge and reflection in national accounts or development policies and lack of understanding of the economic significance of land resources and the ecosystem services they produce. These constrains are summarized.

\subsection{Lack of Finance to Implement SLM Related Programmes and Projects}

Although different development partners have participated through facilitation of various SLM interventions, there are still many constrains to accessing resources. These constrains are caused by policy, fiscal, legal, institutional and human resource problems [16]. Consider, for example, that Tanzania is eligible to access funds from 15 sources of climate change finance for the implementation of SLM projects through the UNFCCC and other global climate change initiatives but it has only been able to access 0.14 percent of the available climate change financing [18]. The main reasons given relate to low capacity, particularly on the technical and scientific requirements for funding application. The analysis of district level institutional capacities and capabilities indicate, for example, that many local government agencies, NGOs and community organizations have resources limitations in terms of staff complements, skills and funds. Low technical capacity results in decision making without sufficient knowledge of the proposed interventions. The capacity deficiency has in particular led to knowledge and information gaps: the links between research and extension service remain weak and research findings largely un-communicated [16].

\subsection{Lack of Prioritization}

SLM is not tabled as a critical issue in government planning and thus tends to be subsumed in key Ministry of Agriculture without being singled out as a critical area of intervention in and of itself [4]. As a result, SLM activities receive only a fraction of the national budget. Even then, the budget is channeled through different sectors which are not coordinated leading to duplications of actions, lack of effective scaling-up and continued dependence on donor interventions.

\subsection{Poor Sectoral Linkages}

Different assessments of SLM projects suggest that there is little coordination between actors at all levels. Indeed, SLM projects are funded from different sources depending and their focus depend mainly on priority areas of donors, which does not always respond to specific local needs. Hence, SLM projects in the country have operated almost independent of each other making the assessment of impacts and scaling up of these projects difficult so as the promotion of investments in them. Taking an example of SLM projects in Kilimanjaro (as presented in Table 1), there is little to say about their linkages and sharing of experience among different actors. 
Overall, poor coordination has proved difficult to take advantage of complementarities and opportunities for joint implementation. This sectoral approach has not only limited opportunities for sharing experiences among projects and programmes of different sponsors but has also constrained efforts to identify sustainable sources of funding.

\subsection{Top-Down Approaches}

Historically, SLM and environmental issues have been characterized by inappropriate policies designed from above with little regard for the unique features of livelihood systems in fragile ecosystems. This has led to two related problems; lack of knowledge about traditional land management practices and their integration in policy processes and contradictions between official and customary land management practices. These contradictions have threatened the political power base causing decision makers to refrain from implementing and enforcing policies.

\subsection{Multiplicity of Institutional and Policy Frameworks}

The multiplicity of policy and legal frameworks in the SLM sectors result in duplication of resources resulting in lack of a coherent, coordinated and integrated approach.

\subsection{Lack of Financial Incentives for Adopting SLM}

Alternative livelihood options require knowledge and financial incentives. Currently, over $80 \%$ of Tanzania's population depends on agriculture for their livelihood, and a similar percentage depends on local wood resources for energy and construction. Although several SLM options exist, their uptake is overly low because there is lack of awareness among beneficiaries about the benefits that can be accrued from sustainable natural resources utilization and management [16].

\subsection{The Absence of a Comprehensive Monitoring System}

Despite the formulation of national development strategies and plans, programme delivery by government in Tanzania is still largely sectoral. Some districts have been conducting isolated monitoring of environmental variables but there has not been coordination system at the regional/national level to assess degradation dynamics, leading to underestimation of the extent of problems and the actual costs of remedy.

\section{Opportunities for Adopting Programmatic Approach to Sustainable Land Management}

Combating land degradation and desertification in Tanzania, as it is in most sub-Sahara African countries, will require coordination and sustainable funding. Opportunities for improving coordination and funding that are necessary for adopting a programmatic approach to SLM are seen in the following ways.

1) The Global Mechanism (GM) of the UNCCD has taken the mandate to promote actions leading to coordination, mobilization and channeling of financial resources to assist developing member countries to coordinate and sustain SLM projects. The GM is seeking to formulate an Integrated Investment Framework (IIF) and Integrated Financing Strategy (IFS) for SLM in Tanzania. The IIF is a comprehensive and realistic roadmap of prioritized investments needed for the attainment of SLM in Tanzania. Notably, the IIF will enhance resource mobilization, build capacity and provide effective co-ordination of SLM programmes/projects on the basis of clearly identified priorities. As such IIF is based on five national level assessments, namely; economic valuation of land, promotion of mobilization of innovative financing mechanisms, including from climate change financial mechanisms, financial instruments associated with incentives and market-based mechanisms (IMBMs) and Aid for Trade (AfT) to finance SLM promotion [4].

2) Whereas IIF will provide a systematic framework to mobilize resources, integrated financing strategy (IFS) will focus on ensuring predictable and sustainable financing for SLM in Tanzania. The two will facilitate the innovative blending and application of various financing instruments from different sources, and channeling these to investments in SLM [4]. Some work has already been done to identify available financial resources at the country level that could be allocated to finance investments in SLM. However, the achievement of these ob- 
jectives will require institutional and policy reforms. It is proposed that the National SLM Agency be established. The National SLM Agency will play the catalytic role in aligning SLM activities to the proposed IIF/IFS. It is envisaged that the proposed Agency will be empowered by law. At the national level, some work has been done to take stock of relevant projects and programmes (planned and on-going) with a view to proposing an entry point for the Agency and specific SLM budget allocations [16].

3) Up-scaling of current SLM adaptation activities and creating synergies across the agro-ecological zones in relevant SLM sectors (Wildlife, Agriculture, Water and Forestry). Proposals for up-scaling SLM projects have already been prepared as summarized in Table 2 .

4) While local financial contributions to SLM have remained overly low, it is confirmed that Tanzania has not utilized the available external sources. For example, there is almost no any support drawn from the available Special Climate Change Fund (SCCF), Strategic Priority for Adaptation (SPA), Least Developed Countries Fund (LDCF), etc. There are also wide range of funding opportunities that have been identified including innovative sources such as the trade and market access and carbon trading that offers prospects for investments in SLM [18]. With the proposed IIF and IFS, Tanzania stands a chance to mobilize resources and coordinate SLM activities in ways that will address current institutional and financial problems.

\section{Conclusions}

This paper provides a situational analysis of environmental resources of the Kilimanjaro ecosystem, which suggests that land degradation has increasingly manifested in different ways: high trends for soil erosion, pastoral-farmer and human-wildlife conflicts; low trend for pasture and fodder, native vegetation, accessibility to key resources in grazing areas and wildlife corridors as well as the diversity and distribution ranges of all the surrounding ecosystems. It is also suggested that there is a declining agro-forestry system particularly following land fragmentations. These conditions sustain land degradation, which in turn, supports the growth of poor population. Coupled with challenges of climate change and the increase of different kinds of livelihood insecurities in rural areas, poverty continues to be a challenge in global efforts to attain SLM and sustainable development.

The bioregional model as used in this paper facilitates reflections on human-nature relations and how threats to land resources in Kilimanjaro are a function of such relations. Coordinated efforts towards improved

\section{Table 2. Proposed strategies for up-scaling SLM activities across the agro-ecological zones in Tanzania.}

\begin{tabular}{|c|c|}
\hline Objectives & Proposed activities \\
\hline $\begin{array}{l}\text { To mainstream SLM issues } \\
\text { in the national agenda and } \\
\text { relevant sectors of the } \\
\text { national budgeting } \\
\text { framework }\end{array}$ & $\begin{array}{l}\text { 1) Harmonize SLM policies/entry points in national budgeting process in the budget preparation cycles } \\
\text { of local government authorities (LGAs) and sectoral ministries. } \\
\text { 2) Support policy dialogue on SLM-related initiatives in national and regional initiatives on CAADP } \\
\text { and trade. } \\
\text { 3) Develop a legislative/regulatory framework for SLM-related activities. } \\
\text { 4) Facilitate technical assistance, EIF national implementation. } \\
\text { 5) Harmonize SLM policies/entry points in national budgeting process in the budget preparation cycles } \\
\text { of local government authorities (LGAs) and sectoral ministries. } \\
\text { 6) Support policy dialogue on SLM-related initiatives in national and regional initiatives on CAADP } \\
\text { and trade. } \\
\text { 7) Develop a legislative/regulatory framework for SLM-related activities. } \\
\text { 8) Facilitate technical assistance, EIF national implementation. }\end{array}$ \\
\hline $\begin{array}{l}\text { To promote alternative } \\
\text { sources of energy for both } \\
\text { industrial and domestic use } \\
\text { and adoption of clean } \\
\text { technologies in industry }\end{array}$ & $\begin{array}{l}\text { 1) Upscale existing miombo project to develop the national co-generation framework for the tobacco } \\
\text { and mining industries (finance incentive structure). } \\
\text { 2) Develop a strategic utilization framework for the biofuel industry, codes and standards, promotion of } \\
\text { alternative sources of energy and co-financing of clean technology practices. } \\
\text { 3) Assist stakeholders to access CDM funds by providing technical assistance to mobilize technical and } \\
\text { financial resources. } \\
\text { 4) Promote green businesses. }\end{array}$ \\
\hline $\begin{array}{l}\text { To enhance incomes of } \\
\text { farmers by addressing } \\
\text { structural market } \\
\text { inefficiencies in the } \\
\text { agriculture, forestry and } \\
\text { wildlife sectors }\end{array}$ & $\begin{array}{l}\text { 1) Enhance extension services in rangeland management and agriculture sectors (credit facility for } \\
\text { livestock owners, bulking centres and inputs). } \\
\text { 2) Support national certification schemes. } \\
\text { 3) Promote on-farm dairy farming. }\end{array}$ \\
\hline
\end{tabular}

Source: [4]: page 34 . 
livelihoods through SLM remain an important tool for achieving sustainable development in the region. It is also noted that although the trend of land degradation is still high at the national level, the approach taken by the Global Mechanism of the United Nations Convention to Combat Desertification (UNCCD) offers an opportunity for improvements in SLM through financial mobilization and coordination of activities. Yet, specific-site assessments of different thematic areas of SLM will be required to arrive at the desired goal of coordinating, financing and mainstreaming SLM activities. These assessments will be useful for correct interpretations of existing challenges and opportunities for adopting pragmatic approaches to SLM.

\section{Acknowledgements}

I would like to extend my appreciation to the Kilimanjaro Regional Office and the UNDP/GEF Kilimanjaro project office for inviting me to give a keynote address in the conference. Special appreciation goes to Dr. Fransis Mkanda, the project technical adviser, for encouraging me to provide the note and the preparation of this paper. Thanks to my anonymous reviewers for their useful comments.

\section{References}

[1] Pingali, P., Schneider, K. and Zurek, M. (2014) Poverty, Agriculture and the Environment: The Case of Sub-Saharan Africa. Marginality. Springer, Berlin.

[2] FAO (2011) The State of the World's Land and Water Resources for Food and Agriculture (SOLAW)—Managing Systems at Risk. Earthscan, Rome.

[3] United Nations (2012) The Future We Want. Washington DC.

[4] Awere-Gyekye, K. (2014) Tanzania: Integrated Investment Framework (IIF) and Integrated Financing Strategy (IFS) for Sustainable Land Management. Draft Report for Global Mechanism, Rome.

[5] United Republic of Tanzania (URT) (2012) Tanzania in Figures, Dar es Salaam, Government Printers.

[6] Ajathi, H. and Krumme, K. (2002) Ecosystem-Based Conservation Strategies for Protected Areas in Savanna: With Special Reference to East Africa. University of Essen, Essen.

[7] Brunckhorst, D. (2000) Bioregionalism Planning: Resource Management beyond the New Millennium. Routledge, London.

[8] Noe, C. (2003) The Dynamics of Land Use Changes and Their Impacts on the Wildlife Corridor between Mt. Kilimanjaro and Amboseli National Park, Tanzania, Nairobi. LUCID Project, International Livestock Research Institute.

[9] Lambrechts, C., Woodley, B., Hemp, A., Hemp, C. and Nnyiti, P. (2002) Aerial Survey of the Threats to Mt. Kilimanjaro Forests. UNDP, Dar es Salaam.

[10] Misana, S., Majule, A. and Lyaruu, H. (2003) Linkages between Changes in Land Use, Biodiversity and Land Degradation on the Slopes of Mount Kilimanjaro, Tanzania, Nairobi. LUCID Project, International Livestock Research Institute.

[11] Maitima, J. and Olson, J. (2002) Biodiversity in Agricultural Productive Systems. Land Use Impacts and Dynamics, Working Paper 3.

[12] Soini, E. (2005) Changing Livelihoods on the Slopes of Mt. Kilimanjaro, Tanzania: Challenges and Opportunities in the Chagga Homegarden System. Agroforestry Systems, 64, 157-167. http://dx.doi.org/10.1007/s10457-004-1023-y

[13] Hemp, A. (2006) The Banana Forests of Kilimanjaro: Biodiversity and Conservation of the Chagga Homegardens. Forest Diversity and Management, 2, 133-155.

[14] Ylhäisi, J. (2004) Indigenous Forests Fragmentation and the Significance of Ethnic Forests for Conservation in the North Pare, the Eastern Arc Mountains, Tanzania. Fennia, 182, 109-132.

[15] Murusuri, N. and Nderumaki, V. (2013) Bringing Communities into the Management of Protected Areas: Experience from COMPACT Mt. Kilimanjaro. In: Brown, J. and Hay-Edie, T., Eds., COMPACT Engaging Local Communities in Stewardship of World Heritage, United Nations Development Programme, New York, 68-78.

[16] Mashauri, S. (2014) Integrated Investment Framework for SLM in Tanzania: Financial Diagnosis and Stocktaking. Volume 3. Global Mechanism, United Nations Convention to Combat Desertification, Rome.

[17] Soussan, J. (2014) Integrated Investment Framework for SLM in Tanzania: The Value of Land in Tabora Region, Tanzania. The Global Mechanism, United Nations Convention to Combat Desertification, Rome.

[18] Yanda, P. (2010) Sustainable Land Management and Climate Change Finance in Tanzania: National Level Assessment 
Report. Vol. 5. Global Mechanism, the United Nations Convention to Combat Desertification, Rome.

[19] Canigiani, E. and Bingi, S. (2014) Integrated Investment Framework for SLM in Tanzania. Mobilizing Aid for Trade for Agriculture: Context Analysis. Vol. 6. The Global Mechanism, United Nations Convention to Combat Desertification, Rome. 
Scientific Research Publishing (SCIRP) is one of the largest Open Access journal publishers. It is currently publishing more than 200 open access, online, peer-reviewed journals covering a wide range of academic disciplines. SCIRP serves the worldwide academic communities and contributes to the progress and application of science with its publication.

Other selected journals from SCIRP are listed as below. Submit your manuscript to us via either submit@scirp.org or Online Submission Portal.
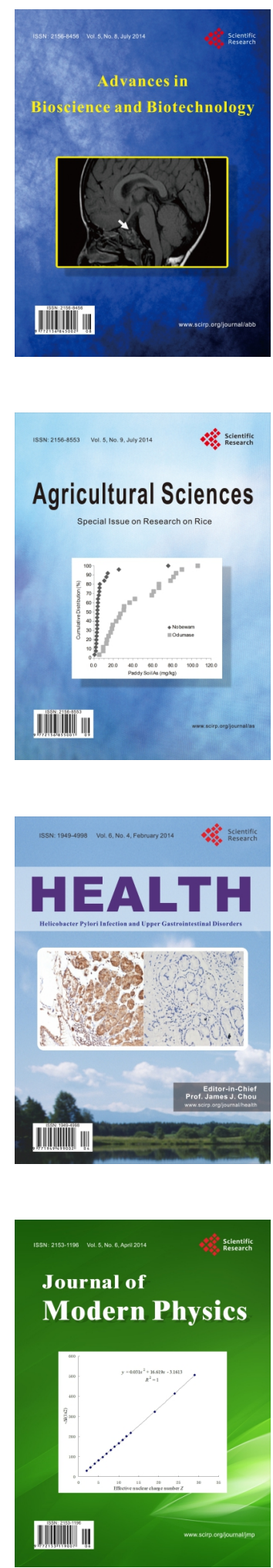
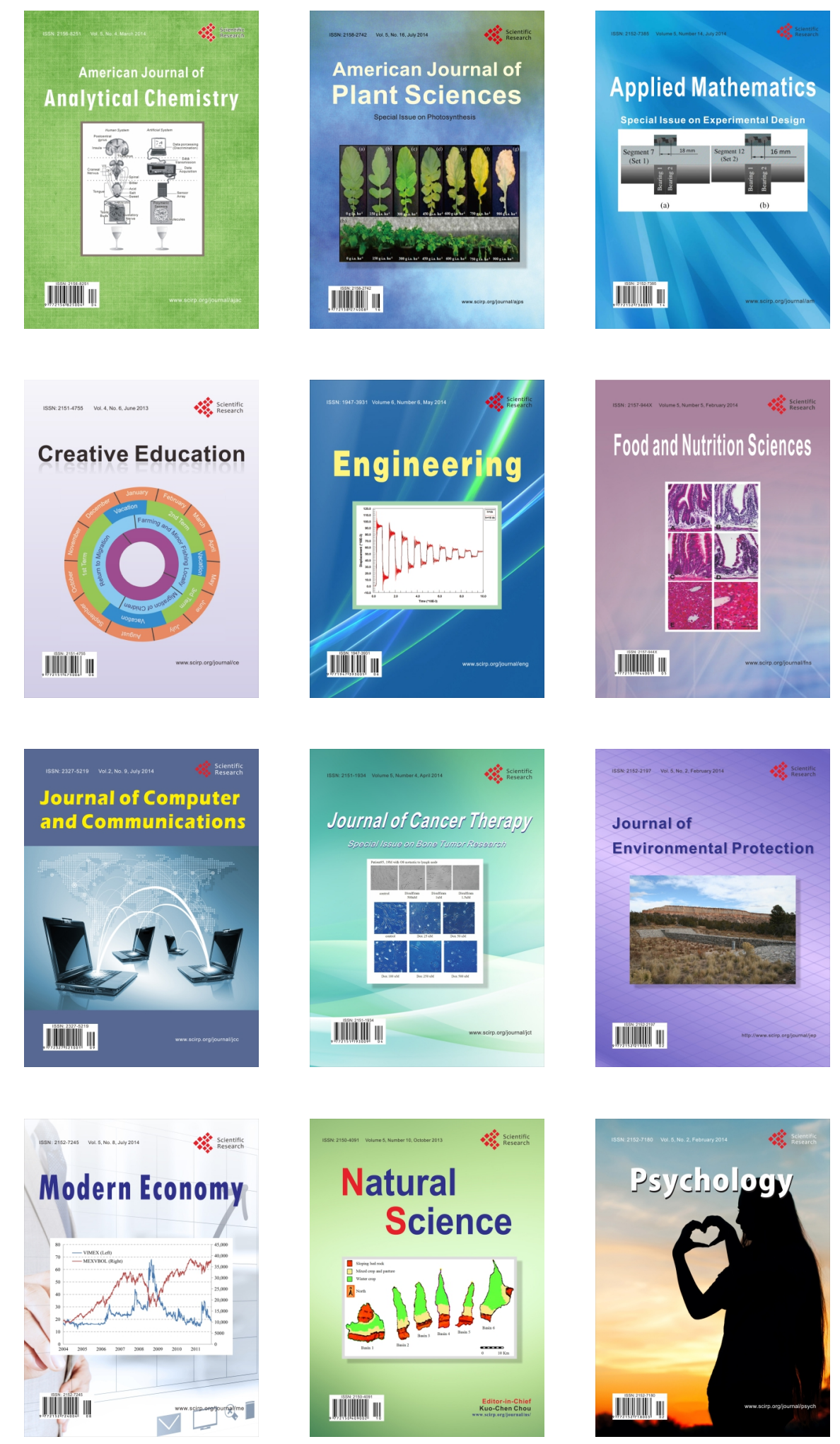